\title{
Ultrasound-assisted Extraction of Oil from Calophyllum inophyllum Seeds: Statistical Optimisation using Box-Behnken Design
}

\author{
Faiznur Mohd. Fuad, Khairiah Abd. Karim* and Mashitah Mat Don \\ School of Chemical Engineering, Universiti Sains Malaysia, \\ Engineering Campus, 14300 Nibong Tebal, Pulau Pinang, Malaysia \\ *Corresponding author: chkhairiah@usm.my
}

Published online: 25 August 2016

To cite this article: Mohd. Fuad, F. Abd. Karim, K. \& Mat Don, M. (2016). Ultrasound-assisted extraction of oil from Calophyllum inophyllum seeds: Statistical optimisation using Box-Behnken design. J. Phys. Sci., 27(2), 103-121, DOI: 10.21315/jps2016.27.2.8

To link to this article: http://dx.doi.org/10.21315/jps2016.27.2.8

\begin{abstract}
Ultrasound-assisted extraction (UAE) of oil from Calophyllum inophyllum Linn seeds was studied and the effects of four factors (extraction time, ultrasound power, extraction temperature, and liquid to solid $(L / S)$ ratio) on the oil yield were optimised by using a statistical tool. Specifically, the optimisation was carried out by employing a BoxBehnken statistical experimental design. The experimental data were fitted to a quadratic model using multiple regression analysis giving high determination coefficient value $\left(R^{2}\right)$ of 0.984 . The predicted oil yield was optimum (56.2\%) when the extraction were conducted for $21 \mathrm{~min}, 210 \mathrm{~W}$ ultrasound power, $42^{\circ} \mathrm{C}$ extraction temperature and $21 \mathrm{ml} / \mathrm{g}$ $L / S$ ratio. Based on the model summary statistics, the experimental values agreed closely with the predicted values, indicating an excellent fit of the model used. The results indicated that Response Surface Methodology (RSM) was effective for optimising the $U A E$ conditions of oil from $C$. inophyllum seeds.
\end{abstract}

Keywords: Calophyllum inophyllum, ultrasound, seed oil, Box-Behnken design, optimisation

\section{INTRODUCTION}

Calophyllum inophyllum Linn is an oilseed ornamental evergreen tree, commonly known as Penaga Laut in Malaysia. It belongs to the Clusiaceae family having average height of 8-20 m with a broad spreading crown of irregular branches. $C$. inophyllum are also known as Alexandrian laurel, Tamanu, Bintangor, Nyamplung and Kamani. ${ }^{1-3}$ A number of medicinal and therapeutic properties have been described to various parts of Calophyllum multipurpose tree, including the treatment of rheumatism, varicose veins, hemorrhoids and chronic ulcers. ${ }^{4}$ 
The seeds of $C$. inophyllum have a very high oil content and most of them are unsaturated oleic and linoleic acid. ${ }^{5}$ The oil does not only possess antiinflammatory, antimicrobial and antiaging properties, but it can be used to treat diabetic sores, anal fissures, sunburn, dry skin, blisters and sore throat. ${ }^{4,6}$ The pain relieving properties of $C$. inophyllum oil has been used traditionally to relieve neuralgin, rheumatism and sciatica. ${ }^{6}$

Traditional techniques of extraction, such as heating, boiling or refluxing, used for the solvent extraction of natural products are associated with longer extraction times and lower yields, use of large amount of organic solvents, and poor extraction efficiency. ${ }^{7}$ Thus, developing an optimised novel extraction technology is necessary in pharmaceutical, food and cosmetic industries.

Recently, ultrasound-assisted extraction (UAE) has been developed as a novel technique to extract oil from plants. UAE is being used widely in extraction of oil from various types of seeds including pomegranate, papaya, tobacco, grape, hemp and black seed. ${ }^{8-13}$ This technique has been considered as a desirable method of extraction offering many advantages. Such advantages include less extraction time, low extraction temperature, and high extraction efficiency. ${ }^{14} \mathrm{In}$ addition, it is inexpensive, environment friendly and simple to operate. ${ }^{15,16}$ The mechanism of ultrasonic enhancement is mainly attributed to behaviour of cavitation bubbles upon propagation of acoustic waves. The collapsing of these bubbles can produce chemical, physical and mechanical effects which result in disruption of material matrix, facilitating release of extractable compounds and enhancing mass transfer of solvent into the sample thus increasing the release of target compounds from matrix into the solvent. ${ }^{17}$

Response surface methodology (RSM) is a collection of mathematical and statistical techniques for designing experiments, building models, evaluating the effects of several factors, and obtaining optimum condition of factors for desirable responses. RSM provides the relationship between one or more measured dependent responses and a number of input factors. ${ }^{18}$ The optimisation process involves studying the response of the statistically designed combinations, estimating the coefficients by fitting it in a mathematical model that fits best the experimental conditions, predicting the response of the fitted model, and checking the adequacy of the model. ${ }^{19}$

Box-Behnken design (BBD) is one of the most common RSM tools, which has been widely used by researchers for optimisation of experimental trials. It is more efficient to conduct experiments using a BBD over traditional methods because it simplifies the complexity of the experimental trials needed to evaluate multiple variables and their interactions. ${ }^{20} \mathrm{BBD}$ is not only capable in determining the accurate optimum values of experimental parameters but also provides the 
possibility to evaluate the interaction between variables with a reduced number of experiments. ${ }^{21}$ BBD does not contain combinations for which all factors are simultaneous at their highest or lowest levels. It is also useful in avoiding experiments performed under extreme conditions, for which unsatisfactory results are often obtained. ${ }^{22}$ Its other advantages including the following: less number of experiments involved; suitability for multiple variables, which can reveal possible interactions between variable; relativity search between multiple variables; and finding the most suitable correlation and forecast response. ${ }^{18}$

Even though UAE technique offers many advantages, the feasibility of using UAE for the extraction of $C$. inophyllum seed oil has not yet been explored in the literature. Furthermore, to our best knowledge, reports on optimisation of extraction conditions on $C$. inophyllum oil using RSM are very limited. Hence, the objectives of our study is to investigate and optimise the effect of UAE process variables such as extraction time, ultrasonic power, extraction temperature and liquid to solid (L/S) ratio on the yield of C. inophyllum oil using Box-Behnken response surface design. The optimised controlled conditions determined in this study should offer important reference values for any subsequent studies.

\section{EXPERIMENTAL}

\subsection{Material}

C. inophyllum fruits were collected from Taman Kerian, Parit Buntar, Perak, Malaysia. The species was identified by Dr. Rahmad Zakaria (USM Herbarium 11565) from the School of Biological Sciences, Universiti Sains Malaysia. Prior to extraction, the fruits were slightly crushed to obtain the seeds. Then, the cleaned seeds were ground in a laboratory mill and sieved using a 10-mesh (pore size $2 \mathrm{~mm}$ ) sieve. Analytical grade n-hexane (Merck) was used as extraction solvent.

\subsection{Moisture Content of the Seeds}

The moisture content of the seeds was determined by oven drying method at 105 $\pm 1^{\circ} \mathrm{C}$ for $24 \mathrm{~h} .^{23}$ The moisture content (wet basis) was calculated as:

$$
\text { Moisture content }(\%)=\frac{\left(m_{i}-m_{d}\right)}{m_{i}} \times 100
$$

where $m_{i}$ and $m_{d}$ is the initial and final mass of the seed (g), respectively. ${ }^{24}$ 


\subsection{Ultrasound-assisted Extraction}

The extraction was performed using an ultrasonic water bath (Transsonic Digital S Model T 840DH), with internal tank dimension $327 \mathrm{~mm} \times 300 \mathrm{~mm} \times 200 \mathrm{~mm}$, volume 181 , having a power consumption of $1100 \mathrm{~W}$ and a fixed operating frequency of $40 \mathrm{kHz}$. It is equipped with adjustable power output from 70 to 250 W. The ultrasonic bath was filled with water approximately $2 / 3$ of its volume. The seed sample $(5 \mathrm{~g})$ and the extracting solvent, n-hexane was placed in an Erlenmayer flask $(250 \mathrm{ml})$ covered with aluminium foil. Then, the flask was immersed into the centre position of the ultrasonic bath and this position was kept constant throughout the experiments. During extraction, the temperature was controlled and maintained at the desired level by water circulating from a water bath. After extraction, the liquid extract was separated from the seed residue by using a centrifuge at $4000 \mathrm{rpm}$ for $20 \mathrm{~min}$. The solvent was then removed by using a rotary evaporator and the oil obtained were dried until a constant weight was reached. The extracted oil was collected in a pre-weighed $50 \mathrm{ml}$ beaker for the yield calculation.

\subsection{Determination of C. inophyllum Oil Yield}

Extraction yield of C. inophyllum oil was calculated using Equation (2):

$$
Y=\frac{M_{1}}{M_{0}} \times 100 \%
$$

where $Y$ is the extraction yield of $C$. inophyllum oil (\%), $M_{1}$ is the mass of $C$. inophyllum oil extracted from the sample $(\mathrm{g})$ and $M_{0}$ is the mass of the sample used $(\mathrm{g}) .^{25}$ The mass of $C$. inophyllum oil extracted from the sample, $M_{1}$ was calculated by the difference between the mass of beaker containing the oil and the mass of the empty beaker used.

\subsection{Experimental Design}

A four-factor, three-level BBD was employed to determine the optimal conditions for UAE of $C$. inophyllum oil. In order to evaluate the effect of process variables, 29 experiments including five replicates at the central point were performed randomly. Four independent variables involved in this study were extraction time $\left(\mathrm{X}_{1}\right)$, ultrasonic power $\left(\mathrm{X}_{2}\right)$, extraction temperature $\left(\mathrm{X}_{3}\right)$ and liquid to solid ratio $\left(\mathrm{X}_{4}\right)$, while the dependent variable was the yield of $C$. inophyllum oil (Y). The ranges of the independent variables were chosen based on the results of preliminary experiments. All independent variables and their respective levels used in BBD were shown in Table 1. 
Table 1: Independent variables and their respective coded levels employed in BBD.

\begin{tabular}{lccc}
\hline \multirow{2}{*}{ Independent variables } & \multicolumn{3}{c}{ Levels } \\
\cline { 2 - 4 } & -1 & 0 & +1 \\
\hline Extraction time, $\mathrm{X}_{1}(\mathrm{~min})$ & 15 & 20 & 25 \\
Ultrasonic power, $\mathrm{X}_{2}(\mathrm{~W})$ & 190 & 210 & 230 \\
Extraction temperature, $\mathrm{X}_{3}\left({ }^{\circ} \mathrm{C}\right)$ & 35 & 40 & 45 \\
Liquid to solid ratio, $\mathrm{X}_{4}(\mathrm{ml} / \mathrm{g})$ & 15 & 20 & 25 \\
\hline
\end{tabular}

Each of these independent variables were coded at three levels between $-1,0$ and +1 . The coding of the variables was done according to the following equation: ${ }^{26}$

$$
x_{i}=\frac{x_{i}-x_{z}}{\Delta x_{i}} i=1,2,3, \ldots, k
$$

Where $x_{i}$ is the dimensionless value of an independent variable, $X_{i}$ is the real value of an independent variable, $X_{Z}$ is the real value of an independent variable at the centre point, and $\Delta x_{i}$ is the step change of the real value of the variable $i$ corresponding to a variation of a unit for the dimensionless value of the variable $i$. The experimental data were analysed by multiple regressions to fit the following quadratic polynomial model:

$$
Y=\beta_{0}+\sum_{i=1}^{4} \beta_{i} X_{i}+\sum_{i \measuredangle j}^{3} \sum_{j}^{4} \beta_{i j} X i X_{j}+\sum_{i=1}^{4} \beta_{i j} X_{2}^{i}
$$

Where $Y$ is the predicted response and $\beta_{o}$ is an intercept. $B_{i}, \beta_{i i}$ and $\beta_{i j}$ are regression coefficients for linear, quadratic, and interactive terms, respectively. $X_{i}$ and $X_{j}$ are the coded independent variables. ${ }^{27}$

\subsection{Statistical Method}

The statistical analysis was carried out using Design Expert (Version 6.0.6, StatEase Inc., Minneapolis, Minnesota, USA). Modeling of data started with a quadratic model including linear, squared and interaction terms. The adequacy of the model was determined by evaluating the coefficient of determination $\left(R^{2}\right)$, the lack of fit, adequate precision and the F-test value obtained from the analysis of variance (ANOVA) that was generated. The regression coefficients obtained from the model were then used for the statistical calculations to generate response 
surface plots. $^{28}$ Additional confirmation experiments were subsequently conducted to verify the validity of the statistical model.

\section{RESULTS AND DISCUSSION}

\subsection{Statistical Analysis and Model Fitting}

The C. inophyllum seeds used in this study have a moisture content of $9.45 \%$. The extraction parameters involved in the UAE of $C$. inophyllum oil were optimised using the BBD. The experimental design matrices with their respective response of the C. inophyllum oil yield are shown in Table 2 .

Table 2: Box-Behnken experimental design and results for extraction yield of $C$. inophyllum oil.

\begin{tabular}{|c|c|c|c|c|c|c|}
\hline \multirow{2}{*}{ No. } & \multirow{2}{*}{$\mathrm{X}_{1}(\mathrm{~min})$} & \multirow{2}{*}{$\mathrm{X}_{2}(\mathrm{~W})$} & \multirow{2}{*}{$\mathrm{X}_{3}\left({ }^{\circ} \mathrm{C}\right)$} & \multirow{2}{*}{$\mathrm{X}_{4}(\mathrm{ml} / \mathrm{g})$} & \multicolumn{2}{|c|}{ Y, oil yield (\%) } \\
\hline & & & & & Experimental & Predicted \\
\hline 1 & 20 & 190 & 35 & 20 & 52.79 & 52.67 \\
\hline 2 & 20 & 210 & 45 & 15 & 54.84 & 54.91 \\
\hline 3 & 20 & 210 & 40 & 20 & 56.24 & 56.01 \\
\hline 4 & 15 & 190 & 40 & 20 & 53.45 & 53.43 \\
\hline 5 & 25 & 210 & 35 & 20 & 53.87 & 53.83 \\
\hline 6 & 20 & 230 & 40 & 25 & 54.88 & 54.90 \\
\hline 7 & 25 & 210 & 40 & 25 & 54.56 & 54.52 \\
\hline 8 & 15 & 210 & 40 & 15 & 52.93 & 52.92 \\
\hline 9 & 25 & 190 & 40 & 20 & 54.12 & 54.28 \\
\hline 10 & 20 & 190 & 40 & 25 & 53.82 & 53.94 \\
\hline 11 & 20 & 210 & 35 & 15 & 52.08 & 52.18 \\
\hline 12 & 20 & 190 & 40 & 15 & 53.67 & 53.71 \\
\hline 13 & 15 & 210 & 40 & 25 & 54.52 & 54.60 \\
\hline 14 & 20 & 230 & 35 & 20 & 53.25 & 53.37 \\
\hline 15 & 25 & 210 & 45 & 20 & 54.89 & 54.93 \\
\hline 16 & 15 & 230 & 40 & 20 & 54.03 & 53.87 \\
\hline 17 & 20 & 210 & 35 & 25 & 54.16 & 54.08 \\
\hline 18 & 25 & 210 & 40 & 15 & 54.77 & 54.64 \\
\hline
\end{tabular}


Table 3: (continued)

\begin{tabular}{|c|c|c|c|c|c|c|}
\hline \multirow{2}{*}{ No. } & \multirow{2}{*}{$\mathrm{X}_{1}(\min )$} & \multirow{2}{*}{$\mathrm{X}_{2}(\mathrm{~W})$} & \multirow{2}{*}{$\mathrm{X}_{3}\left({ }^{\circ} \mathrm{C}\right)$} & \multirow{2}{*}{$\mathrm{X}_{4}(\mathrm{ml} / \mathrm{g})$} & \multicolumn{2}{|c|}{ Y, oil yield (\%) } \\
\hline & & & & & Experimental & Predicted \\
\hline 19 & 25 & 230 & 40 & 20 & 54.65 & 54.66 \\
\hline 20 & 20 & 230 & 45 & 20 & 54.61 & 54.69 \\
\hline 21 & 20 & 210 & 40 & 20 & 55.59 & 56.01 \\
\hline 22 & 20 & 210 & 45 & 25 & 54.69 & 54.58 \\
\hline 23 & 20 & 190 & 45 & 20 & 54.75 & 54.58 \\
\hline 24 & 15 & 210 & 45 & 20 & 54.53 & 54.62 \\
\hline 25 & 20 & 210 & 40 & 20 & 56.02 & 56.01 \\
\hline 26 & 20 & 210 & 40 & 20 & 55.93 & 56.01 \\
\hline 27 & 20 & 210 & 40 & 20 & 56.28 & 56.01 \\
\hline 28 & 20 & 230 & 40 & 15 & 53.63 & 53.56 \\
\hline 29 & 15 & 210 & 35 & 20 & 52.48 & 52.50 \\
\hline
\end{tabular}

$X_{1}=$ Extraction time, $X_{2}=$ Ultrasonic power $(W), X_{3}=$ Extraction temperature, $X_{4}=$ liquid to solid ratio $(\mathrm{ml} / \mathrm{g})$

The resulting oil yield ranged between $52.08 \%$ and $56.28 \%$ where the maximum oil yield was obtained under the following extraction conditions: $20 \mathrm{~min}$ extraction time, $210 \mathrm{~W}$ ultrasonic power, $40^{\circ} \mathrm{C}$ extraction temperature and $20 \mathrm{ml} / \mathrm{g} \mathrm{L} / \mathrm{S}$ ratio. By applying multiple regression analysis on the experimental data, the predicted response variable and the independent variables were found to correlate by a second-order polynomial equation. The equation was expressed in terms of coded factors, described as follows:

$\mathrm{Y}=56.01+0.41 \mathrm{X}_{1}+0.20 \mathrm{X}_{2}+0.81 \mathrm{X}_{3}+0.39 \mathrm{X}_{4}-0.90 \mathrm{X}_{1}^{2}-1.05 \mathrm{X}_{2}^{2}-1.14 \mathrm{X}_{3}^{2}-0.94 \mathrm{X}_{4}^{2}$

$-0.012 \mathrm{X}_{1} \mathrm{X}_{2}-0.26 \mathrm{X}_{1} \mathrm{X}_{3}-0.45 \mathrm{X}_{1} \mathrm{X}_{4}-0.15 \mathrm{X}_{2} \mathrm{X}_{3}+0.28 \mathrm{X}_{2} \mathrm{X}_{4}-0.56 \mathrm{X}_{3} \mathrm{X}_{4}$

The coefficients with single factor represent the effect of that particular factor towards the C. inophyllum oil yield, while those with second-order terms and two different factors represent the quadratic and interactive effects, respectively. Analysis of variance (ANOVA) were used to test the adequacy and fitness of the models. Table 3 provides the regression coefficient values of equation obtained from the statistical analysis results. 
Table 4: ANOVA of the regression quadratic model for the prediction of the $C$. inophyllum oil yield.

\begin{tabular}{lccccc}
\hline Source & Sum of squares & Degrees of freedom & Mean square & $F$ value & $p$-value \\
\hline Model & 31.93 & 14 & 2.28 & 61.54 & $<0.0001$ \\
Residual & 0.52 & 14 & 0.04 & & \\
Lack of fit & 0.21 & 10 & 0.02 & 0.27 & 0.9566 \\
Pure error & 0.31 & 4 & 0.08 & & \\
Cor total & 32.45 & 28 & & & \\
$R^{2}=0.9840 ; R 2=R_{A d j}^{2}=0.9680 ;=R_{\text {pred }}^{2}$ & $0.9478 ;$ C.V.\% $=0.35 ;$ Adeq precision $=27.66$
\end{tabular}

The regression model of $C$. inophyllum oil yield was considered highly significant owing to the values of both $F$ value and $p$-value, which were 61.54 and $<0.0001$, respectively. Meanwhile, the $p$-value for the lack of fit $(0.9566)$ was higher than 0.05 . This shows that it was not significant relative to the pure error and indicates that the fitting model is adequate to describe the experimental data. These two values confirmed the goodness-of-fit and suitability of the regression model. The adequacy of the model was further tested by evaluating the determination coefficient $\left(R^{2}\right)$. The determination coefficient $\left(R^{2}=0.9840\right)$ indicates that only $1.6 \%$ of the total variation are not explained by the model. The value of adjusted determination coefficient $\left(R_{A d j}^{2}=0.9680\right)$ also confirmed that the model was highly significant. At the same time, a relatively low value of coefficient of variation $(\mathrm{C} . \mathrm{V} . \%=0.35)$ clearly proves that the experimental values of regression model were precise and reliable. Adequate precision is a measure of the range in predicted response relative to its associated error and a value greater than four indicate that the model can be used within the region of operation. ${ }^{29}$ In this study, an adequate precision value of 27.66 indicated that the model has an adequate signal. In conclusion, the established model is adequate for prediction in the range of experimental variables. The significance of each coefficient measured using $F$-value and $p$-value is listed in Table 4 . For each terms in the model, a large $F$-value and a small $P$-value would imply a more significant effect on the respective response variable. ${ }^{30}$ All regression coefficients were significant $(P<0.05)$ towards the response variable except for two interactive coefficients, which were the interaction between extraction time and ultrasonic power $\left(\mathrm{X}_{1} \mathrm{X}_{2}\right)$ as well as ultrasonic power and extraction temperature $\left(\mathrm{X}_{2} \mathrm{X}_{3}\right)$. 
Table 5: Estimated coefficients and significance test for linear, quadratic and interactive factors of the regression model.

\begin{tabular}{cccccc}
\hline Source & Coefficient estimate & Standard error & $F$ value & $p$-value & Significance \\
\hline $\mathrm{X}_{1}$ & 0.41 & 0.06 & 54.43 & $<0.0001$ & $\mathrm{~S}$ \\
$\mathrm{X}_{2}$ & 0.20 & 0.06 & 13.50 & 0.0025 & $\mathrm{~S}$ \\
$\mathrm{X}_{3}$ & 0.81 & 0.06 & 210.68 & $<0.0001$ & $\mathrm{~S}$ \\
$\mathrm{X}_{4}$ & 0.39 & 0.06 & 49.88 & $<0.0001$ & $\mathrm{~S}$ \\
$\mathrm{X}_{1}^{2}$ & -0.90 & 0.08 & 143.26 & $<0.0001$ & $\mathrm{~S}$ \\
$\mathrm{X}_{2}{ }^{2}$ & -1.05 & 0.08 & 192.40 & $<0.0001$ & $\mathrm{~S}$ \\
$\mathrm{X}_{3}^{2}$ & -1.14 & 0.08 & 226.35 & $<0.0001$ & $\mathrm{~S}$ \\
$\mathrm{X}_{4}{ }^{2}$ & -0.94 & 0.08 & 153.33 & $<0.0001$ & $\mathrm{~S}$ \\
$\mathrm{X}_{1} \mathrm{X}_{2}$ & -0.01 & 0.10 & 0.02 & 0.8985 & $\mathrm{~N}-\mathrm{S}$ \\
$\mathrm{X}_{1} \mathrm{X}_{3}$ & -0.26 & 0.10 & 7.16 & 0.0181 & $\mathrm{~S}$ \\
$\mathrm{X}_{1} \mathrm{X}_{4}$ & -0.45 & 0.10 & 21.85 & 0.0004 & $\mathrm{~S}$ \\
$\mathrm{X}_{2} \mathrm{X}_{3}$ & -0.15 & 0.10 & 2.43 & 0.1415 & $\mathrm{~N}-\mathrm{S}$ \\
$\mathrm{X}_{2} \mathrm{X}_{4}$ & 0.28 & 0.10 & 8.16 & 0.0127 & $\mathrm{~S}$ \\
$\mathrm{X}_{3} \mathrm{X}_{4}$ & -0.56 & 0.10 & 33.54 & $<0.0001$ & $\mathrm{~S}$ \\
\hline$S$ & & & &
\end{tabular}

$S=$ Significant, $N-S=$ Non-significant

\subsection{Comparison of Experimental and Predicted C. inophyllum Oil Yield}

A regression model provides the ability to predict future observations on the response ( $C$. inophyllum oil yield) corresponding to particular values of the variables. However, verification of the model is essential to ensure that adequate approximation to the actual values is done. Proceeding without proper analysis and optimisation of the fitted response surface would probably cause disingenuous results. ${ }^{28}$ Therefore, diagnostic plots such as the experimental versus predicted values shown in Figure 1 were used to judge the model adequacy and display the correlation between experimental and predicted values. Each of the experimental value is compared to the predicted ones computed from the model. The data points on this plot are positioned close to the straight line and signify that there is sufficient agreement between the actual data and the model data. This result implies that the regression model used in this extraction process were able to predict optimum operating conditions for $C$. inophyllum oil extraction. 


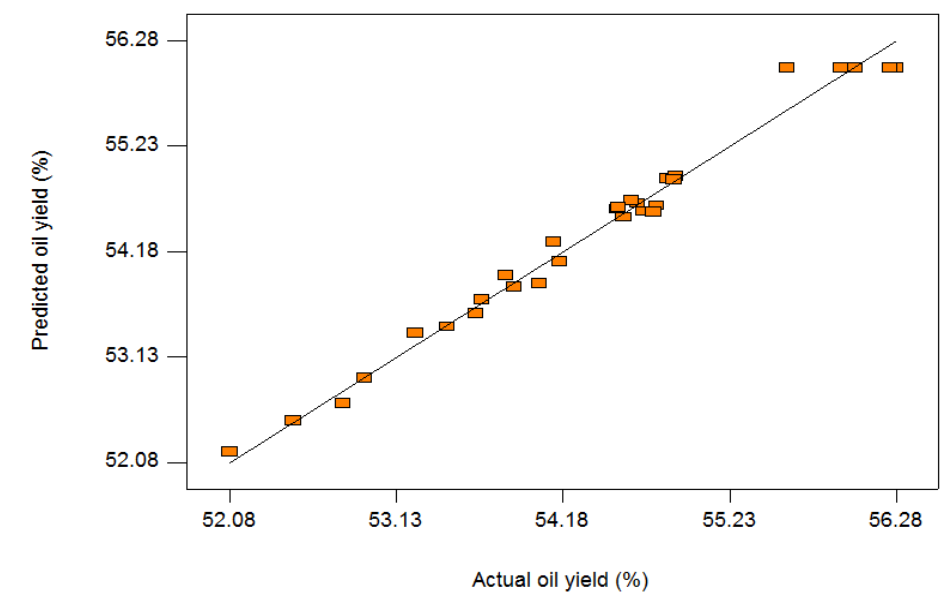

Figure 1: Comparison between predicted and experimental oil yield.

\subsection{Response Surface Optimisation of the C. inophyllum Oil Extraction Conditions}

Three-dimensional response surface and two-dimensional contour plots generated by the Design Expert software version 6.0.6 were used to visualise the relationship between independent and dependent variables and the interactions between two variables. Different shapes of the contour plots indicate whether mutual interactions between the independent variables are significant or not. The circular contour plots indicate the negligible interactions between the corresponding variables, while an elliptical contour plots indicate the significant interactions between the corresponding variables. ${ }^{31}$ The three-dimensional representations of the response surfaces generated by the model are shown in Figure 2, 3, 4 and 5. Among these four variables studied, two variables were kept constant at their respective zero level, when the other two variables within the experimental range were depicted in the three-dimensional surface plots. 


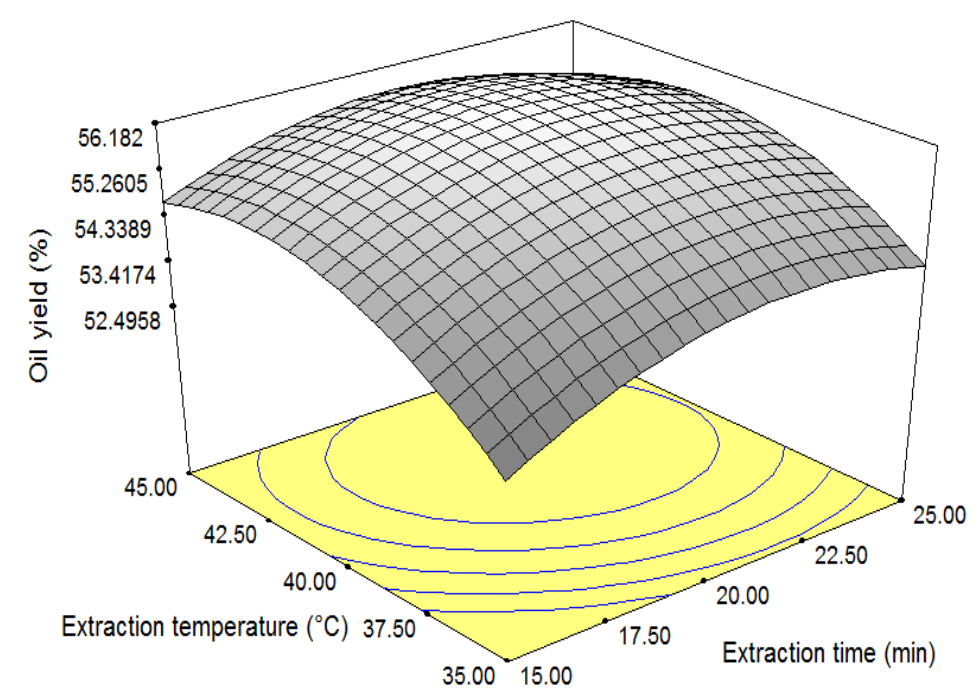

Figure 2: Response surface plot showing the effects of extraction time and extraction temperature on the yield of $C$. inophyllum oil. The ultrasonic power and L/S ratio were at $210 \mathrm{~W}$ and $20 \mathrm{ml} \mathrm{g}^{-1}$, respectively.

Figure 2 illustrates the effects of extraction time and extraction temperature on $C$. inophyllum oil yield at an ultrasonic power of $210 \mathrm{~W}$ and $\mathrm{L} / \mathrm{S}$ ratio of $20 \mathrm{ml} \mathrm{g}^{-1}$. Increases in extraction time from $15 \mathrm{~min}$ to $20 \mathrm{~min}$ and extraction temperature from $35^{\circ} \mathrm{C}$ to $40^{\circ} \mathrm{C}$ gradually increased the oil yield and then it began to level off and decrease slightly at elevated temperatures $\left(>40^{\circ} \mathrm{C}\right)$ and longer extraction time (>20 min). The initial sharp increase in the extraction yield was due to the large oil concentration gradient between the extracting solvent and the seeds and also due to easier extraction of oil from the most outer part of the seeds. As the extraction time proceeded, the concentration gradient decreased; as the mass transfer was increased with continuous exposure to ultrasound, the extraction became difficult due to interior part of the seeds. The continuous increase in the release of the oil resulted in a saturated solvent, leading to a negligible mass transfer and extraction. ${ }^{32}$

According to Jovanovic-Malinovska et al., ${ }^{33}$ this observation can be well explained by Fick's second law of diffusion, which stated that the final equilibrium between the solute concentrations in the solid matrix (seeds) and in the bulk solution (solvent) will be achieved after certain time. Hence, an excessive extraction time did not lead to enhanced oil yield. Therefore, the final equilibrium between the oil concentration within the seeds and in the n-hexane was achieved at approximately $20 \mathrm{~min}$ of extraction time. This result was in agreement with the findings reported by Zhang et al. ${ }^{34}$ on the UAE of epimedin 
A, B, C and icariin from Herba Epimedii. The increasing trend of the oil yield along the increasing temperature $\left(35^{\circ} \mathrm{C}\right.$ to $\left.40^{\circ} \mathrm{C}\right)$ is probably due to the improvement of the mass transfer resulting from the increased solubility of $C$. inophyllum oil and the decreased viscosity of the solvent. ${ }^{35} \mathrm{On}$ the other hand, the reverse trend could be explained by a combination of acoustic cavitation and thermal effect. The temperature displayed a positive effect on vapour pressure. Therefore, high temperature led to the increase in the vapour pressure of solvent molecules within cavitation micro-bubbles, causing the damping of the bubble collapse and decrease in cavitation intensity. ${ }^{36}$ Sun et al. ${ }^{37}$ reported the same trend in their research on all-trans- $\beta$-carotene extraction from citrus peels by using ultrasound treatment.

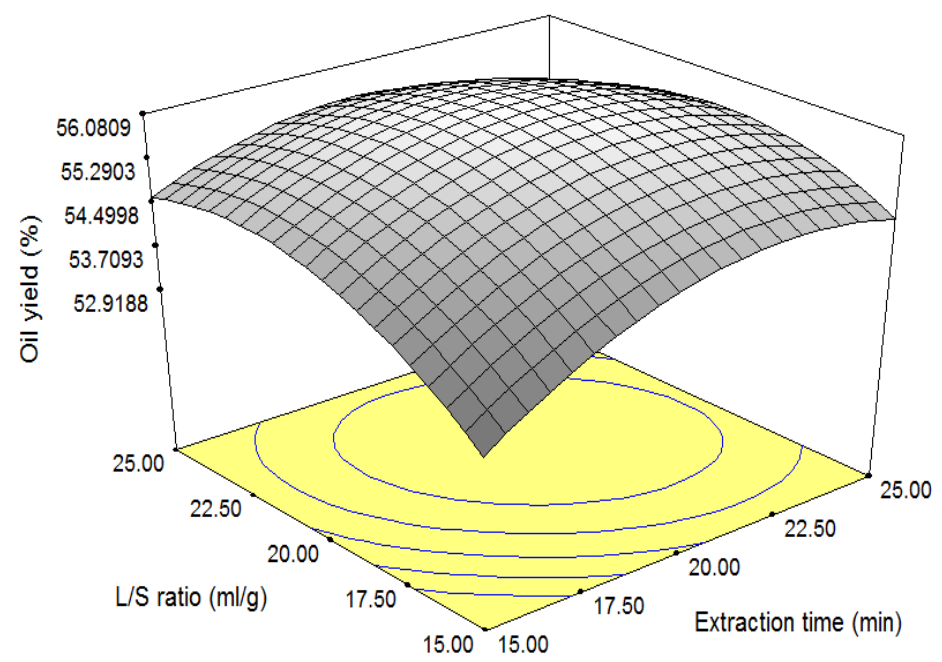

Figure 3: Response surface plot showing the effects of extraction time and L/S ratio on the yield of $C$. inophyllum oil. The ultrasonic power and extraction temperature were at $210 \mathrm{~W}$ and $40^{\circ} \mathrm{C}$, respectively.

Figure 3 shows the effects of extraction time and L/S ratio on C. inophyllum oil yield when the ultrasonic power and extraction temperature were maintained at $210 \mathrm{~W}$ and $40^{\circ} \mathrm{C}$. The oil yield increased significantly at a lower range of extraction time (15 to $20 \mathrm{~min})$ and $\mathrm{L} / \mathrm{S}$ ratio $\left(15\right.$ to $\left.20 \mathrm{ml} \mathrm{g}^{-1}\right)$. In contrast, when extraction time and $\mathrm{L} / \mathrm{S}$ ratio were raised to a higher level, the oil yield did not show any remarkable improvement. A high ratio of liquid to solid material implied greater concentration difference between the interior plant cells and the exterior solvent, and the diffusion of oil occurred more quickly. In this case, increasing $\mathrm{L} / \mathrm{S}$ ratio from 15 to $20 \mathrm{ml} \mathrm{g}^{-1}$ created a larger concentration difference between the interior seeds and exterior solvent, thus enhancing the oil yield. The 
oil yield did not improve further when L/S ratio was increased higher from 20 to $35 \mathrm{ml} \mathrm{g}^{-1}$ due to the prolonged distance of diffusion towards the interior tissues. ${ }^{38}$ Fu et al. ${ }^{39}$ studied UAE of oleanolic and ursolic acids from pomegranate (Punica granatum L.) flowers and they found out that solvent to material ratio of $20 \mathrm{ml} \mathrm{g}^{-1}$ was the best condition for the extraction and a larger ratio did not increase the extraction yield.

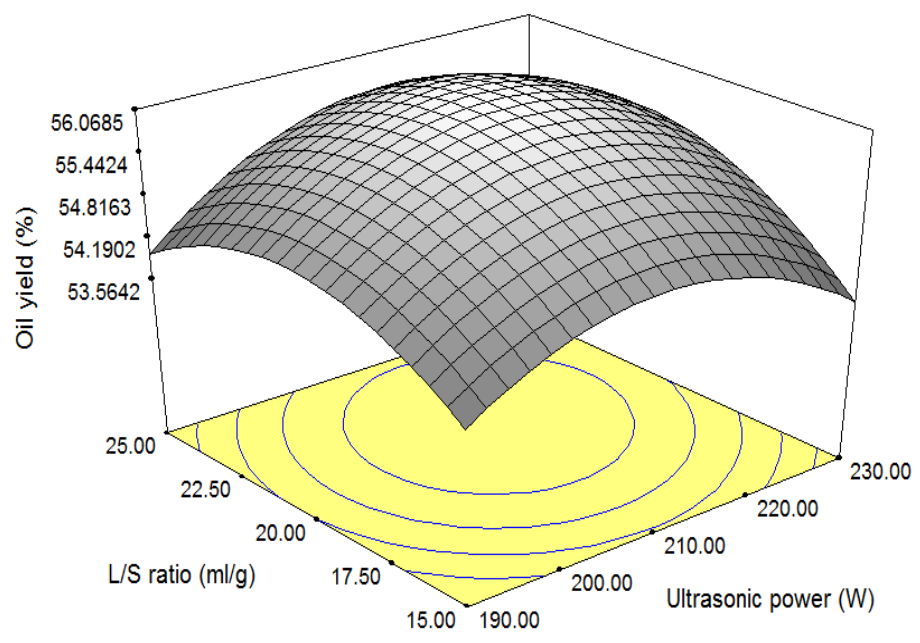

Figure 4: Response surface plot showing the effects of ultrasonic power and L/S ratio on the yield of $C$. inophyllum oil. The extraction time and extraction temperature were at $20 \mathrm{~min}$ and $40^{\circ} \mathrm{C}$, respectively.

Figure 4 illustrates the response surface plot for the effects of ultrasonic power and $\mathrm{L} / \mathrm{S}$ ratio on $C$. inophyllum oil yield when the extraction time and extraction temperature were held constant at $20 \mathrm{~min}$ and $40^{\circ} \mathrm{C}$ respectively. It can be seen that higher oil yield was reached at an ultrasonic power between $190 \mathrm{~W}$ and $210 \mathrm{~W}$ and $\mathrm{L} / \mathrm{S}$ ratio between $15 \mathrm{ml} \mathrm{g}^{-1}$ and $20 \mathrm{ml} \mathrm{g}^{-1}$. An increase in ultrasound power promotes a more vigorous destruction of the seed's cell walls. The higher the ultrasound power, the more solvent could enter the interior of the cells and the more oil will be released into the solvent, hence improving the extraction efficiency. ${ }^{40}$ However, beyond $210 \mathrm{~W}$ and $20 \mathrm{ml} \mathrm{g}^{-1}$, the oil yield started to reduce. This observation can be explained by the increase of acoustic intensity with the increasing of ultrasonic power. In this case more bubbles were formed which hampers the propagation of shock waves and the bubbles may coalesce to form bigger ones and implode weakly. Therefore, the extraction efficiency would decrease. ${ }^{41}$ Sun et $\mathrm{al}^{42}$ in their study on the UAE of five isoflavones from Iris tectorum Maxim reported the same trend where the highest extraction yield for 
all isoflavones were achieved at an ultrasound power of $150 \mathrm{~W}$. The extraction yield decreased when the power was above $150 \mathrm{~W}$.

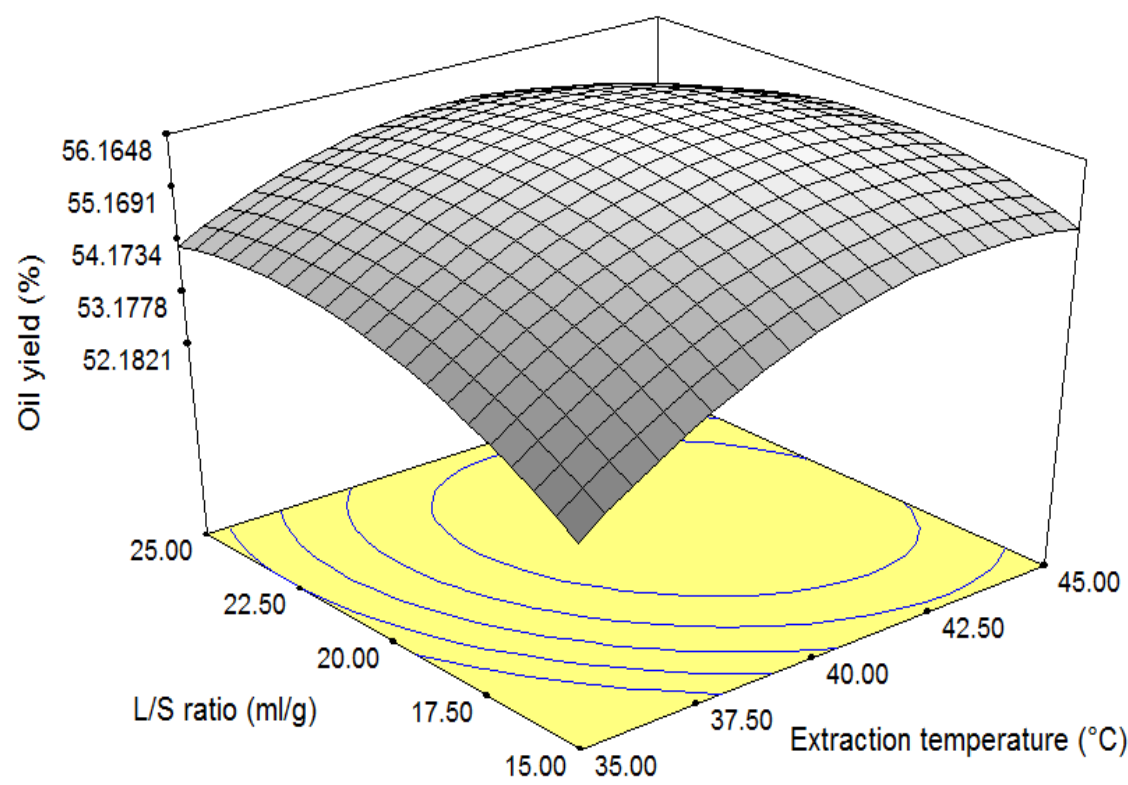

Figure 5: Response surface plot showing the effects of extraction temperature and $\mathrm{L} / \mathrm{S}$ ratio on the yield of $C$. inophyllum oil. The extraction time and ultrasonic power were at $20 \mathrm{~min}$ and $210 \mathrm{~W}$, respectively.

Figure 5 shows the effects of extraction temperature and $\mathrm{L} / \mathrm{S}$ ratio on $C$. inophyllum oil yield whereas the extraction time and ultrasonic power were set constant at their respective centre values of $20 \mathrm{~min}$ and $210 \mathrm{~W}$. The oil yield increased as the extraction temperature and $\mathrm{L} / \mathrm{S}$ ratio increases in the range between $35^{\circ} \mathrm{C}$ to $40^{\circ} \mathrm{C}$ and 15 to $20 \mathrm{ml} \mathrm{g}^{-1}$ respectively. The highest oil yield was obtained at approximately $40^{\circ} \mathrm{C}$ with $\mathrm{L} / \mathrm{S}$ ratio of $20 \mathrm{ml} \mathrm{g}^{-1}$. Further variation in the temperature $\left(40^{\circ} \mathrm{C}\right.$ to $\left.45^{\circ} \mathrm{C}\right)$ and $\mathrm{L} / \mathrm{S}$ ratio $\left(20\right.$ to $\left.25 \mathrm{ml} \mathrm{g}^{-1}\right)$ however caused a slight decrease in the oil yield.

\subsection{Validation of the Predictive Model}

The regression model proposed by BBD predicts optimum conditions which gives the highest $C$. inophyllum oil yield. Optimum conditions identified were as follows: extraction time $20.8 \mathrm{~min}$, ultrasonic power $211.74 \mathrm{~W}$, extraction temperature $41.54^{\circ} \mathrm{C}$ and $\mathrm{L} / \mathrm{S}$ ratio of $20.5 \mathrm{ml} \mathrm{g}$. The combination of these extraction conditions were expected to obtain maximum oil yield of $56.2 \%$. For 
operational convenience, the optimum conditions were $21 \mathrm{~min}, 210 \mathrm{~W}, 42^{\circ} \mathrm{C}$ and $21 \mathrm{ml} \mathrm{g}^{-1}$ for extraction time, ultrasonic power, extraction temperature and $\mathrm{L} / \mathrm{S}$ ratio, respectively. However, validation of the predicted optimum conditions is required to determine the adequacy and reliability of the model equation. Therefore, five sets of confirmatory experiments were conducted at the suggested optimum extraction conditions. As tabulated in Table 5, the experimental oil yield was $56.03 \%$ and it was close to the predicted value (56.2\%). Additionally, the percentage error differences between the experimental and predicted values were in the range of $0.30-3.75 \%(<5 \%)$, thus indicating that the predicted conditions and response were verified for optimising UAE of $C$. inophyllum oil. As a result, the model developed by BBD was suitable and could be effectively used to optimise the extraction parameters of $C$. inophyllum oil extraction.

Table 5: Experimental and predicted C. inophyllum oil yield under optimum conditions.

\begin{tabular}{cccccccc}
\hline \multicolumn{4}{c}{ Optimum conditions } & \multicolumn{3}{c}{ Y, Oil yield (\%) } & \multirow{2}{*}{ Error (\%) } \\
\cline { 1 - 5 } Run & $\mathrm{X}_{1}(\mathrm{~min})$ & $\mathrm{X}_{2}(\mathrm{~W})$ & $\mathrm{X} 3\left({ }^{\circ} \mathrm{C}\right)$ & $\mathrm{X} 4(\mathrm{ml} \mathrm{g}-1)$ & Experimental & Predicted & \\
\cline { 1 - 5 } 1 & 21 & 210 & 42 & 21 & 55.13 & 56.20 & 1.90 \\
2 & 21 & 210 & 42 & 21 & 56.41 & 56.20 & 0.37 \\
3 & 21 & 210 & 42 & 21 & 54.09 & 56.20 & 3.75 \\
4 & 21 & 210 & 42 & 21 & 55.68 & 56.20 & 0.93 \\
5 & 21 & 210 & 42 & 21 & 56.03 & 56.20 & 0.30 \\
\hline
\end{tabular}

$X_{1}=$ Extraction time $; X_{2}=$ Ultrasonic power $; X_{3}=$ Extraction temperature $; X_{4}=L / S$ ratio

The efficiency of UAE technique in extracting oil from $C$. inophyllum seeds was compared to a study reported by Jahirul et al. ${ }^{43}$ They have conducted the extraction of $C$. inophyllum seed oil by using a conventional solvent (hexane) extraction technique. The highest oil yield obtained was approximately $51 \%$ after $8 \mathrm{~h}$ of extraction. In addition, they also used mechanical extraction technique (screw press) in order to obtain the oil. However, this technique was less efficient as it took over an hour to process just one sample and the oil yield was low (approximately 25\%). In contrast, UAE technique in the present study only required 21 min to give a maximum oil yield of $56 \%$. This shows that the application of ultrasound have successfully reduced the extraction time needed, thus making UAE a more effective and promising technique compared to the conventional extraction technique.

\section{CONCLUSION}

The Box-Behnken response surface design was successfully employed to optimise the UAE of oil from C. inophyllum seeds. Four independent variables 
such as extraction time, ultrasound power, extraction temperature and L/S ratio significantly affect the $C$. inophyllum oil yield. The developed model gave a high determination coefficient value $\left(\mathrm{R}^{2}\right)$ of 0.984 , implying a satisfactory fit to the experimental data. The optimum conditions were found to be as follows: extraction time $21 \mathrm{~min}$, ultrasound power $210 \mathrm{~W}$, extraction temperature of $42^{\circ} \mathrm{C}$ and $\mathrm{L} / \mathrm{S}$ ratio $21 \mathrm{ml} \mathrm{g}^{-1}$. Under these optimised conditions, the maximum oil yield observed was $56.03 \%$ and it was in good agreement with those predicted by the regression model.

\section{ACKNOWLEDGEMENT}

The authors gratefully acknowledge the Ministry of Higher Education of Malaysia (MOHE) for MyMaster allocation. The authors would also like to thank Ministry of Higher Education of Malaysia (MOHE) for funding this work through Fundamental Research Grant Scheme (203/PJKIMIA/6071272).

\section{REFERENCES}

1. Ong, H. C. et al. (2011). Comparison of palm oil, Jatropha curcas and Calophyllum inophyllum for biodiesel: A review. Renew. Sustainable Energy Rev., 15, 3501-3515.

2. Rizwanul Fattah, I. M. et al. (2014). Experimental investigation of performance and regulated emissions of a diesel engine with Calophyllum inophyllum biodiesel blends accompanied by oxidation inhibitors. Energy Convers. Manage,, 83, 232-240, DOI: 10.1016/j.enconman.2014.03.069.

3. Lawal, O. S. et al. (2010). Equilibrium, thermodynamic and kinetic studies for the biosorption of aqueous lead(II) ions onto the seed husk of Calophyllum inophyllum. J. Hazard. Mater., 177, 829-835, DOI: 10.1016/j.jhazmat.2009.12.108.

4. Crane, S. et al. (2005). Composition of fatty acids triacylglycerols and unsaponifiable matter in Calophyllum calaba L. oil from Guadeloupe. Phytochem., 66(15), 1825-1831, DOI: 10.1016/j.phytochem.2005. 06.009 .

5. Sanjid, A. et al. (2013). Impact of palm, mustard, waste cooking oil and Calophyllum inophyllum biofuels on performance and emission of CI engine. Renew. Sustain. Energy Rev., 27, 664-682, DOI: 10.1016/j.rser.2013.07.059.

6. Chavan, S. B., Kumbhar, R. R. \& Deshmukh, R. B. (2013). Callophyllum inophyllum Linn ("honne") oil, a source for biodiesel production. Res. J. Chem. Sci., 3, 24-31. 
7. Ghitescu, R.-E. et al. (2015). Optimization of ultrasound-assisted extraction of polyphenols from spruce wood bark. Ultrason. Sonochem., 22, 535-541, DOI: 10.1016/j.ultsonch.2014.07.013.

8. Tian, Y. et al. (2013). Optimization of ultrasonic-assisted extraction of pomegranate (Punica granatum L.) seed oil. Ultrason. Sonochem., 20, 202-208, DOI: 10.1016/j.ultsonch.2012.07.010.

9. Samaram, S. et al. (2013). Ultrasound-assisted extraction (UAE) and solvent extraction of papaya seed oil: Yield, fatty acid composition and triacylglycerol profile. Mol., 18, 12474-12487, DOI: 10.3390/molecules 181012474.

10. Stanisavljević, I. T. , Lazić, M. L. \& Veljković, V. B. (2007). Ultrasonic extraction of oil from tobacco (Nicotiana tabacum L.) seeds. Ultrason. Sonochem., 14, 646-652.

11. Da Porto, C., Porretto, E. \& Decorti, D. (2013). Comparison of ultrasound-assisted extraction with conventional extraction methods of oil and polyphenols from grape (Vitis vinifera L.) seeds. Ultrason. Sonochem., 20, 1076-1080, DOI: 10.1016/j.ultsonch.2012.12.002.

12. Lin, J.-Y. et al. (2012). Ultrasonic extraction of hempseed oil. J. Food Process Eng., 35(1), 76-90.

13. Abdullah, M. \& Koc, A. B. (2013). Kinetics of ultrasound-assisted oil extraction from black seed (Nigella sativa). J. Food Process. Preserv., 37(5), 814-823, DOI: 10.1111/j.1745-4549.2012.00704.x.

14. Jiang, C. et al. (2014). Optimization for ultrasound-assisted extraction of polysaccharides with antioxidant activity in vitro from the aerial root of Ficus microcarpa. Carbohydr. Polym., 110, 10-17, DOI: 10.1016/j.carbpol.2014.03.027.

15. Chen, W. et al. (2012). Optimization of ultrasonic-assisted extraction of water-soluble polysaccharides from Boletus edulis mycelia using response surface methodology. Carbohydr. Polym., 87(1), 614-619, DOI: 10.1016/j.carbpol.2011.08.029.

16. Hossain, M. B. et al. (2014). Ultrasonic extraction of steroidal alkaloids from potato peel waste. Ultrason. Sonochem., 21, 1470-1476, DOI: 10.1016/j.ultsonch.2014.01.023.

17. Maran, J. P. \& Priya, B. (2014). Ultrasound-assisted extraction of polysaccharide from Nephelium lappaceum L. fruit peel. Int. J. Biol. Macromol., 70, 530-536, DOI: 10.1016/j.ijbiomac.2014.07.032.

18. Shu, G. et al. (2013). Application of Box-Behnken design in optimization for crude polysaccharides from fruits of Tribulus terristris L. J. Chem. Pharm. Res., 5(10), 342-350.

19. Dong, C.-H. et al. (2009). Application of Box-Behnken design in optimisation for polysaccharides extraction from cultured mycelium of Cordyceps sinensis. Food Bioprod. Process., 87, 139-144, DOI: 10.1016/j.fbp.2008.06.004. 
20. Wang, Y., Liu, Y. \& Hu, Y. (2014). Optimization of polysaccharides extraction from Trametes robiniophila and its antioxidant activities. Carbohydr. Polym., 111, 324-332, DOI: 10.1016/j.carbpol.2014.03.083.

21. Maran, J. P. \& Priya, B. (2015). Ultrasound-assisted extraction of pectin from sisal waste. Carbohydr. Polym., 115, 732-738, DOI: 10.1016/j.carbpol.2014.07.058.

22. Dahmoune, F. et al. (2014). Pistacia lentiscus leaves as a source of phenolic compounds: Microwave-assisted extraction optimized and compared withultrasound-assisted and conventional solvent extraction. Ind. Crop Prod., 61, 31-40, DOI: 10.1016/j.indcrop.2014.06.035.

23. Bamgboye, A. I. \& Adebayo, S. E. (2012). Seed moisture dependent on physical and mechanical properties of Jatropha curcas. J. Agri. Technol., $8,13-26$.

24. Abdullah, M. H. R. O., Ch'ng, P. E. \& Lim, T. H. (2010). Determination of some physical properties of nutmeg (Myristica fragrans) seeds. Res. $J$. Appl. Sci. Eng. Technol., 2, 669-672.

25. Hu, A.J. et al. (2010). Kinetic model and technology of ultrasound extraction of safflower seed oil. J. Food Process. Eng., 35, 278-294, DOI: $10.1111 / \mathrm{j} .1745-4530.2010 .00589 . x$.

26. Prakash Maran, J. et al. (2013). Box-Behnken design based statistical modeling for ultrasound-assisted extraction of corn silk polysaccharide. Carbohydr. Polym., 92, 604-611, DOI: 10.1016/j.carbpol.2012.09.020.

27. Zheng, Y., Li, Y. \& Wang, W. D. (2014). Optimization of ultrasonicassisted extraction and in vitro antioxidant activities of polysaccharides from Trametes orientalis. Carbohydr. Polym., 111, 315-323, DOI: 10.1016/j.carbpol.2014.04.034.

28. Swamy, G. J., Sangamithra, A. \& Chandrasekar, V. (2014). Response surface modeling and process optimization of aqueous extraction of natural pigments from Beta vulgaris using Box-Behnken design of experiments. Dyes Pigm., 111, 64-74, DOI: 10.1016/j.dyepig. 2014.05.028.

29. Minjares-Fuentes, R. et al. (2014). Ultrasound-assisted extraction of pectins from grape pomace using citric acid: A response surface methodology approach. Carbohydr. Polym., 106, 179-189, DOI: 10.1016/j.carbpol.2014.02.013.

30. Yolmeh, M., Najafi, M. B. H. \& Farhoosh, R. (2014). Optimisation of ultrasound-assisted extraction of natural pigment from annatto seeds by response surface methodology (RSM). Food Chem., 155, 319-324, DOI:10.1016/j.foodchem.2014.01.059.

31. Fan, T. et al. (2015). Optimization of enzymolysis-ultrasonic assisted extraction of polysaccharides from Momordica charabtia L. by response surface methodology. Carbohydr. Polym., 115, 701-706, DOI: 10.1016/j.carbpol.2014.09.009. 
32. Dey, S. \& Rathod, V. K. (2013). Ultrasound assisted extraction of $\beta$ carotene from Spirulina platensis. Ultrason. Sonochem., 20, 271-276, DOI: 10.1016/j.ultsonch.2012.05.010.

33. Jovanovic-Malinovska, R., Kuzmanova, S. \& Winkelhausen, E. (2015). Application of ultrasound for enhanced extraction of prebiotic oligosaccharides from selected fruits and vegetables. Ultrason. Sonochem., 22, 446-453, DOI: 10.1016/j.ultsonch.2014.07.016.

34. Zhang, H.-F. etc. (2008). Simultaneous extraction of epimedin A, B, C and icariin from Herba Epimedii by ultrasonic technique. Ultrason. Sonochem., 15, 376-385, DOI: 10.1016/j.ultsonch.2007.09.002.

35. Zhang, H.-F. et al. (2009). Ultrasonic-assisted extraction of epimedin C from fresh leaves of Epimedium and extraction mechanism. Innov. Food Sci. Emerg. Technol., 10, 54-60.

36. Xu, Y. \& Pan, S. (2013). Effects of various factors of ultrasonic treatment on the extraction yield of all-trans-lycopene from red grapefruit (Citrus paradise Macf.). Ultrason. Sonochem., 20, 1026-1032, DOI: 10.1016/j.ultsonch.2013.01.006.

37. Sun, Y. et al. (2011). Effects of different factors of ultrasound treatment on the extraction yield of the all-trans- $\beta$-carotene from citrus peels. Ultrason. Sonochem., 18, 243-249, DOI: 10.1016/j.ultsonch.2010. 05.014 .

38. Ying, Z., Han, X. \& Li, J. (2011). Ultrasound-assisted extraction of polysaccharides from mulberry leaves. Food Chem., 127, 1273-1279, DOI: 10.1016/j.foodchem.2011.01.083.

39. Fu, Q. et al. (2014). Extraction optimization of oleanolic and ursolic acids frompomegranate (Punica granatum L.) flowers. Food Bioprod. Process., 92, 321-327, DOI: 10.1016/j.fbp.2012.12.006.

40. $\mathrm{Zu}, \mathrm{G}$. et al. (2012). Ultrasound-assisted extraction of carnosic acid and rosmarinic acid using ionic liquid solution from Rosmarinus officinalis. Int. J. Mol. Sci., 13, 11027-11043, DOI: 10.3390/ijms130911027.

41. Fang, X. et al. (2014). Optimization of ultrasonic-assisted extraction of wedelolactone and antioxidant polyphenols from Eclipta prostrate L using response surface methodology. Sep. Purif. Technol., 138, 55-64, DOI: 10.1016/j.seppur.2014.10.007.

42. Sun, Y., Liu, Z. \& Wang, J. (2011). Ultrasound-assisted extraction of five isoflavones from Iris tectorum Maxim. Sep. Purif. Technol., 78, 4954, DOI: 10.1016/j.seppur.2011.01.017.

43. Jahirul, M. I. et al. (2013). Optimisation of bio-oil extraction process from beauty leaf (Calophyllum inophyllum) oil seed as a second generation biodiesel source. Proced. Eng., 56, 619-624, DOI:10.1016/j.proeng. 2013.03.168. 